\title{
Analisis Kesalahan Siswa Berdasarkan Objek Matematika pada Materi Barisan dan Deret di Kelas XI SMA/MA
}

\author{
Ravina Faradilla Syahril ${ }^{1}$, Kartini Kartini ${ }^{2}$ \\ ${ }^{1,2}$ Program Pascasarjana Pendidikan Matematika, Fakultas Keguruan dan Ilmu Pendidikan, Universitas Riau, \\ Jl. Bina Widya KM. 12,5, Pekanbaru, Indonesia \\ faradillaravina@gmail.com
}

\begin{abstract}
This research was motivated by the difficulties of students in mathematics lessons which resulted in students making mistakes in solving math problems. This study aims to analyze the errors made by students in solving mathematics on the material of sequences and series. This type of research is descriptive qualitative research. The subjects in this study were 23 students of class XI MIPA 2 SMAN 1 Bangkinang, Even Semester City. Data collection techniques used are written tests and documentation of student answers. The instrument used is 8 descriptions consisting of 2 questions for each material arithmetic sequence, arithmetic series, geometric series and geometric series. students' errors based on Soedjadi's analysis of mathematical objects, namely, facts, concepts, principles and operations. The results of the analysis carried out showed that the most errors made by students in completing mathematics online and series material were errors with an average percentage of $8.69 \%$. Keywords: Analyze, A squence and Series, Student Error
\end{abstract}

\begin{abstract}
Abstrak
Penelitian ini dilatarbelakangi oleh kesulitan siswa dalam pelajaran matematikayang berakibat bnyaknya siswa melakukan kesalahan dalam menyelesaikan soal matematika. Penelitian ini bertujuan untuk menganalisis kesalahan-kesalahan yang dilakukan siswa dalam menyelesaikan soal matematika pada materi Barisan dan Deret. Jenis penelitian ini adalah penelitian deskriptif kualitatif. Subjek dalam penelitian ini adalah 23 orang siswa kelas XI MIPA 2 SMAN 1 Bangkinang Kota Semester Genap. Teknik pengumpulan data yang digunakan yaitu dengan tes tertulis dan dokumentasi hasil jawaban siswa. Instrumen yang digunakan adalah 8 soal uraian yang terdiri atas 2 soal untuk masing-masing materi barisan aritmetika, deret aritmetika, barisan geometri dan deret geometri. Kesalahan siswa dianalisis berdasarkan objek matematika Soedjadi yaitu, fakta, konsep, prinsip dan operasi. Hasil analisis yang dilakukan, diperoleh kesalahan terbanyak yang dilakukan siswa dalam menyelesaikan soal matematika pada materi barisan dan deret adalah kesalahan fakta dengan rata-rata persentase 8,69\%.
\end{abstract}

Kata kunci: Analisis, Barisan dan Deret, Kesalahan Siswa

Copyright (c) 2021 Ravina Faradilla Syahril, Kartini

$\triangle$ Corresponding author: Kartini

Email Address: kartini@lecturer.unri.ac.id (Kampus Bina Widya Km 12,5 Simpang Baru, Pekanbaru, Indonesia) Received 28 June 2021, Accepted 12 August 2021, Published 28 August 2021

\section{PENDAHULUAN}

Kemajuan Ilmu pengetahuan, teknologi informasi dan komunikasi saat memiliki dampak terhadap kehidupan pada saat ini. Kemajuan IPTEK tersebut salah satunya dipengaruhi oleh peran matematika yang menjadi dasar ilmu pengetahuan lainnya (Lucas dalam Gustianingrum, 2021). Matematika sering kali dijadikan sebagai dasar ilmu pengetahuan lainnya, oleh karena itu matematika dikenal dengan istilah Ratunya Ilmu Pengetahuan. Pentingnya matematika dalam berbagai ilmu pengetahuan menjadikan matematika sebagai salah satu ilmu yang perlu untuk diajarkan pada setiap jenjang pendidikan.

Dalam dunia pendidikan, matematika sering kali dianggap pelajaran yang paling ditakuti dan dihindari oleh siswa, hal ini terjadi karena matematika yang bersifat abstrak sehingga siswa kesulitan dalam memahami permasalahan yang ada dalam matematika. Hal ini sejalan dengan pendapat Agnesti 
\& Amelia (2020) yang mengatakan bahwa Matematika memiliki karakteristik yang berbeda dengan mata pelajaran lain, obyek matematika pada dasarnya adalah abstrak. Kendala dalam pelajaran matematika adalah matematika memiliki karakteristik yaitu mempunyai objek yang bersifat abstrak, sehingga dapat menyebabkan banyak siswa yang sulit terhadap belajar matematika dan siswa mengalami kesulitan ketika mengubah soal cerita menjadi model matematika (Atiqa, Y. Dan Kusrini dalam Hamidah et al., 2018).

Tujuan pembelajaran matematika yang tercantum dalam Permendikbud No.59 Tahun 2014, Tercapai atau tidaknya tujuan pembelajaran ini dapat tergambar dari proses pembelajaran yang dilakukan dalam kelas. Pembelajaran dikatakan berhasil apabila hasil belajar yang diperoleh siswa mengalami peningkatan. Untuk itu peran guru dalam proses pembelajaran dan siswa itu sendiri sangat mempengaruhi proses pembelajaran. Terkait dengan pembelajaran matematika, masih banyak siswa yang mengalami kesulitan sehingga siswa melakukan kesalahan dalam menyelesaikan soal matematika. Dengan adanya kesulitan-kesulitan ini cenderung membuat siswa melakukan kesalahan dalam menyelesaikan soal matematika. Penyebab kesalahan mereka sebagian besar karena kesulitan siswa dalam memahami tujuan dari masalah yang diberikan, memahami apa yang ditanyakan atau kurangnya pemahaman siswa tentang materi yang terkait dengan masalah (Widyawati et al., 2018).

Kesalahan yang dilakukan siswa ketika menyelesaikan persoalan matematika tidak hanya menggambarkan kesulitan belajar siswa, tetapi juga mengungkapkan kekurangan-kekurangan selama proses pembelajaran, sehingga dengan mengetahui kesalahan-kesalahan yang dilakukan siswa dalam menyelesaikan persoalan matematika dapat menjadi langkah awal dalam usaha memperbaiki kualitas pembelajaran (Zaini, 2010). Oleh karena itu, guru harus mengetahui kesalahan-kesalahan dalam pembelajaran dengan mengidentifikasi dan menganalisis kesalahan siswa untuk memperbaiki kualitas pembelajaaran.

Kesalahan menurut Aris Arya Wijaya (2013)merupakan bentuk penyimpangan pada suatu hal yang telah dianggap benar atau bentuk penyimpangan terhadap sesuatu yang telah disepakati sebelumnya. Sedangkan Kurniasih (dalam Ananda et al., 2018) menyatakan bahwa kesalahan merupakan suatu bentuk penyimpangan terhadap hal yang benar, prosedur yang ditetapkan sebelumnya, atau penyimpangan dari suatu yang diharapkan. Sementara itu, analisis kesalahan merupakan suatu upaya untuk mengamati, menemukan, dan mengklasifikasi kesalahan dengan aturan tertentu (Astuty, 2013)

Dalam matematika sendiri kesalahan umum yang dilakukan oleh siswa dalam mengerjakan soal matematika yaitu, kurangnya pengetahuan siswa tentang simbol, kurangnya pemahaman tentang nilai tempat, penggunaan proses yang keliru dan kesalahan perhitungan (Abdurrahman, 2003). Sedangkan Soedjadi (dalam Ananda et al., 2018) mengelompokkan kesalahan siswa dalam menyelesaikan soal matematika menjadi empat yaitu, kesalahan fakta, kesalahan konsep, kesalahan prinsip dan kesalahan operasi. 
Melihat pengaruh yang besar dari kesalahan-kesalahan yang terdapat dalam pengerjaan masalah matematika ini terhadap pemahaman siswa terdadap materi matematika dan hasil belajar siswa, maka peneliti terdorong untuk menganalisis kesalahan matematika siswa yang ditinjau dari kemampuan matematika siswa pada materi barisan dan deret kelas XI SMA/MA yakni pada Kompetensi Dasar (KD) 3.6 Menggeneralisasi pola bilangan dan jumlah pada barisan aritmatika dan geometri; dan 4.6 Menggunakan pola barisan aritmetika atau geometri untuk menyajikan dan menyelesaikan masalah kontekstual (termasuk pertumbuhan, peluruhan, bunga majemuk dan anuitas).

\section{METODE}

Jenis penelitian ini merupakan penelitian deskriptif kualitatif. Menurut Sugiyono (2011). Penelitian kualitatif digunakan untuk meneliti pada kondisi objek yang alamiah, dimana peneliti adalah sebagai instrumen kunci, pengambilan sampel sumber data dilakukan secara purposive dan snowbaal, teknik pengumpulan dengan trianggulasi (gabungan), analisis data bersifat induktif/kualitatif, dan hasil penelitian kualitatif lebih menekankan makna daripada generalisasi. Penelitian deskriptif kualitatif yaitu dengan menggambarkan kesalahan-kesalahan yang dilakukan siswa dengan mengunakan kata-kata. Penelitian ini dilakukan untuk meneliti kesalahan siswa dalam menyelesaikan soal matematika pada materi barisan dan deret. Jenis kesalahan siswa dikelompokkan berdasarkan objek matematika menurut Soedjadi (dalam Ananda et al., 2018) yaitu (1) Kesalaan fakta, kesalahan siswa dalam menyatakan simbol; (2) Kesalahan konsep, kesalahan siswa dapat menggunakan konsep terkait, definisi, serta membedakan mana yang termasuk konsep dan bukan konsep; (3) Kesalahan prinsip, kesalahan siswa dalam meenggunaan rumus, dan; (4) Kesalahan operasi, kesalahan siswa dalam melakukan perhiungan penjumlahan, pengurangan, perkalian dan pembagian.

Subjek dalam penelitian ini adalah siswa kelas XI MIPA 2 SMAN 1 Bangkinang Kota semester genap yang berjumlah 23 orang. Teknik yang digunakan dalam mengumpulkan data pada penelitian ini terdiri dari: 1) Tes tertulis yang dilaksanakan dengan memberikan soal bentuk uraian kepada siswa yang sebelumnya telah mempelajari materi barisan dan deret; 2) Dokumentasi hasil jawaban siswa. Instrumen penelitian yang digunakan dalam penelitian ini adalah 8 soal uraian yang terdiri atas 2 soal masing-masing untuk pokok bahasan barisan aritmetika, deret aritmetika, barisan geometri dan deret geometri.

Teknik analisis data yang digunakan adalah teknik analisis data deskriptif secara kualitatif dan kuantitatif. Data yang yang diperoleh dari tes terulis kemudian dikoreksi dan dilakukan analisis kesalahan. Jenis kesalahan kemudian dideskripsikan pada butir soal dan dilakukan perhitungan persentase banyak siswa melakukan tiap jenis kesalahan. Dari persentase banyak siswa yang melakukan kesalahan, akan terlihat jenis kesalahan apa yang paling banyak dan paling sedikit dilakukan siswa, sehingga dapat dijadikan sebagai pedoman untuk mengambil keputusan guna meminimalisir kesalahan dan memperbaiki proses pembelajaran. Data dideskripsikan secara kuantitatif dalam bentuk persentase. 
Analisis data kuantitatif dilakukan untuk mengetahui persentase kesalahan siswa berdasarkan tingkat kemampuan matematika siswa pada materi dengan rumus:

$$
P=\frac{R}{N} \times 100 \%
$$

dimana:

$\mathrm{P}=$ Persentase jawaban salah

$\mathrm{R}=$ Banyak siswa yang melakukan kesalahan

$\mathrm{N}$ = Banyak siswa menjawab

Data dideskripsikan secara kualitatif melalui kata-kata tertulis. Pengecekkan keabsahan data kualitatif dengan cara triangulasi. Triangulasi adalah teknik pemeriksaan keabsahan data yang memanfaatkan seseuatu yang lain di luar data itu untuk keperluan pengecekkan atau sebagai pembanding terhadap data itu. Soal yang digunakan dalam penelitian ini adalah sebagai berikut.

$\underline{\text { Soal }}$

1. Diberikan sebuah barisan aritmetika. Jika suku ke-5 dari barisan tersebut adalah 43 dan suku ke-7 dari barisan tersebut adalah 57. Tentukan nilai beda dan suku pertama dari barisan tersebut!

2. Laras dan teman-temannya akan melakukan studytour 14 minngu lagi. Setiap minggu mereka menabung di bendahara kelas mereka untuk perjalanan tersebut. Pada minggu pertama, Laras menabung Rp.150.000,00, minggu kedua Rp.200.000,00, minggu ketiga Rp.250.000,00 dan seterusnya. Berapakah tabungan Laras pada minggu ke-14?

3. Dalam sebuah deret aritmetika, diketahui suku keempat dari deret aritmetika tersebut adalah 41 dan suku keduabelas adalah 97. Hitunglah jumlah 25 suku pertama dari deret tersebut!

4. Sebuah rumah produksi snack memproduksi berbagai macam jenis makanan berbahan baku pisang. Rumah produksi ini telah mampu menjual produk olahan mereka hingga ke mancanegara. Pada awal produksi, tempat produksi ini mampu mengolah 50 ton pisang setiap bulannya. Dengan kemajuan teknologi, rumah produksi tersebut mampu meningkatkan penjualan melalui sosial media. Produksi snack berbahan baku pisang ini meningkat 5 ton setiap bulannya. Berapakah jumlah pisang yang diproduksi oleh rumah produksi tersebut selama 1 tahun?

5. Perhatikan barisan geometri berikut!

$4,8,16,32, \ldots$

Tentukanlah rumus suku ke-n dan suku ke 10 dari barisan tersebut!

6. Sejak tahun 2019, Bu Diana dan anaknya mulai memproduksi aneka makanan berbahan baku singkong. Pada satu bulan pertama, mereka mampu menghabiskan 50kg singkong. Produksi makanan berbahan baku singkong tersebut meningkat 2 kali lipat dari produksi pada bulan sebelumnya. Berapakah banyak singkong yang diproduksi Bu Diana dan anaknya pada bulan ke-6?

7. Diketahui suku pertama dan suku ke empat suatu deret geometri berurutan adalah 6 dan $\frac{3}{4}$. Tentukan jumlah 8 suku pertama dari deret geometri tersebut!

8. Sebuah pabrik properti mampu meningkatkan hasil produksi setiap tahunnya mengikuti aturan barisan geometri. Produksi pada tahun kedua adalah 300 unit dan pada tahun keenam adalah 4800 unit. Berapakah hasil produksi pabrik tersebut selama delapan tahun

Instrumen soal telah dilakukan uji instrumen menggunakan uji validitas, reliabilitas, daya pembeda dan tingkat kesukaran. 


\section{HASIL DAN DISKUSI}

Hasil analisis kesalahan siswa untuk setiap jenis kesalahan dapat dilihat pada Tabel 1 berikut. Pada butir soal nomor 1 terdapat satu orang siswa yang melakukan kesalahan fakta dari 23 orang siswa Maka $\frac{1}{23} \times 100 \%$ dan diperoleh persentase kesalahan fakta untuk butir soal nomor 1 adalah $4,34 \%$, begitu pula perhitungan persentase untuk kesalahan lainnya.

Tabel 1. Persentase total kesalahan yang dilakukan siswa

\begin{tabular}{|c|c|c|c|c|}
\hline \multirow{2}{*}{ Butir Soal } & \multicolumn{4}{|c|}{ Total Kesalahan (Siswa) } \\
\cline { 2 - 5 } & Fakta & Konsep & Prinsip & Operasi \\
\hline 1 & $4,34 \%$ & $4,34 \%$ & $8,69 \%$ & $0 \%$ \\
\hline 2 & $4,34 \%$ & $0 \%$ & $0 \%$ & $0 \%$ \\
\hline 3 & $21,73 \%$ & $8,69 \%$ & $4,34 \%$ & $4,34 \%$ \\
\hline 4 & $17,39 \%$ & $0 \%$ & $8,69 \%$ & $4,34 \%$ \\
\hline 5 & $0 \%$ & $4,34 \%$ & $4,34 \%$ & $8,69 \%$ \\
\hline 6 & $4,34 \%$ & $4,34 \%$ & $4,34 \%$ & $0 \%$ \\
\hline 7 & $4,34 \%$ & $4,34 \%$ & $8,69 \%$ & $4,34 \%$ \\
\hline 8 & $13,04 \%$ & $4,34 \%$ & $8,69 \%$ & $0 \%$ \\
\hline Rata-rata Persentase (\%) & $\mathbf{8 , 6 9} \%$ & $\mathbf{3 , 7 9} \%$ & $\mathbf{5 , 5 8} \%$ & $\mathbf{2 , 7 1} \%$ \\
\hline
\end{tabular}

Terlihat pada Tabel 2, jenis kesalahan yang paling banyak dilakukan adalah jenis kesalahan fakta, yaitu dengan rata-rata sebesar $8,69 \%$ dan jenis kesalahan yang paling sedikir dilakukan siswa adalah jenis kesalahan operasi. Rata-rata persentase siswa yang melakukan kesalahan konsep adalah sebesar 3,79\% dan rata-rata persentase siswa yang melakukan kesalahan prinsip adalah sebesar 5,58\%. Berikut merupakan pemaparan contoh-contoh kesalahan yang dilakukan siswauntuk setiap jenis kesalahan yang dilakukan.

\section{Kesalahan Fakta}

Kesalahan fakta merupakan kesalahan siswa dalam menyataan huruf atau simbol-simbol matematika. Beberapa kesalahan fakta secara umum yang dilakukan oleh siswa yaitu siswa salah dalam menyimbolkan suku ke-n dari suatu barisan dan deret. Siswa menyimbolkan suku ke-n dengan simbol $\left(S_{n}\right)$ seharusnya disimbolkan dengan $U_{n}$, ada pula siswa yang menyimbolkan jumlah suku ke-n dengan simbol $\left(U_{n}\right)$, seharusny disimbolkan dengan $S_{n}$. Kesalahan fakta yang dilakukan ini berdampak pada penyelesaian soal yang dilakukan siswa pada butir soal lainnya. Beberapa contoh kesalahan fakta yang dilakukan siswa dapat dilihat pada Gambar 2 berikut.
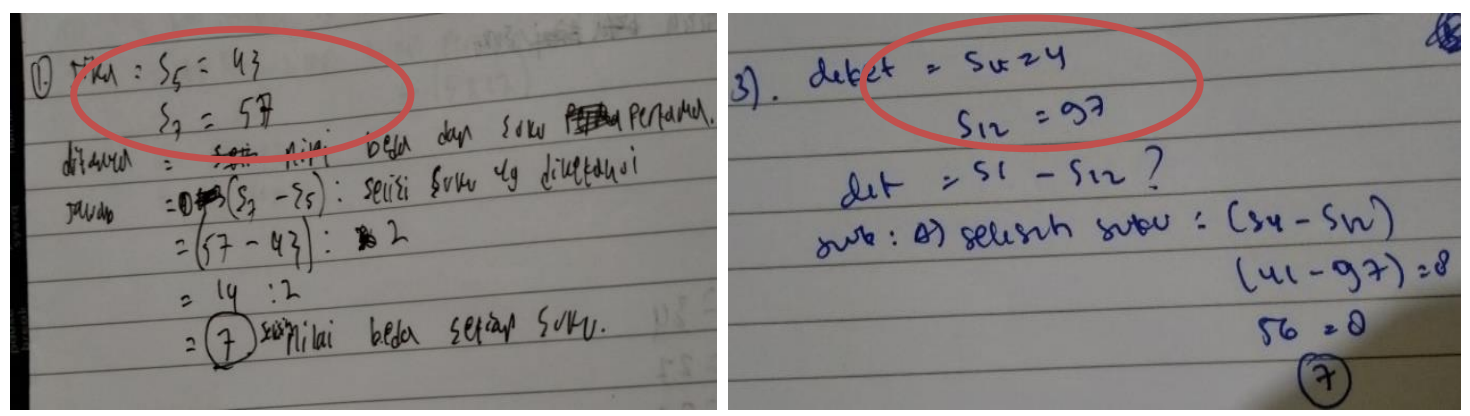

Gambar 2. Contoh Kesalahan Fakta yang Dilakukan Siswa 
Dari Gambar 2, dapat dilihat kesalahan fakta yang dilakukan siswa pada soal nomor 1 dan nomor 3. Pada Soal nomor 1, diketahui nilai suku ke-5 dan suku ke-7. Siswa menuliskan $S_{5}=43$ dan $S_{7}=57$ untuk menyatakan nilai suku ke-5 dan suku ke-7. Untuk hal ini seharusnya disimbolkan dengan $U_{n}$, maka nilai suku ke-5 dan ke-7 berturut-turut seharusnya disimbolkan dengan $U_{5}$ dan $U_{7}$. Kesalahan yang sama juga terjadi pada soal nomor 3, yang mana suku keempat san suku ke duabelas disimbolkan dengan $U_{4}$ dan $U_{12}$.

\section{Kesalahan Konsep}

Kesalahan Konsep adalah kesalahan siswa dapat menggunakan konsep terkait, definisi, serta membedakan mana yang termasuk konsep dan bukan konsep. Kesalahan konsep secara umum yang dilakukan siswadiantaranya siswa belum bisa membedakan suku-suku ke-n dari soal yang diberikan, seperti membedakan $a, U_{1}, U_{4}$ pada soal nomor 3 , salah dalam menyakatakan nilai suku ke-n, dalam membuat model matematika dan menyatakan konsep persamaan dari $U_{n}$, dan kesalahan konsep yang paling banyak terjadi yaitu siswa belum paham membedakankonsep antara barisan dan deret aritmerika dengan barisan dan deret geometri. Berikut contoh kesalahan konsep yang dilakukan siswa.

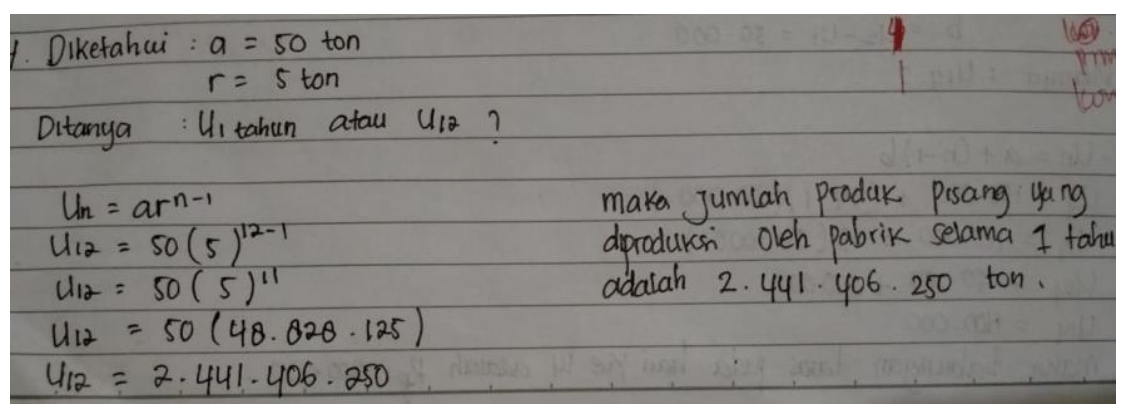

Gambar 3. Contoh Kesalahan Konsep yang Dilakukan Siswa dalam Menyelesaikan Soal Nomor 4

Pada Gambar 3, siswa melakukan kesalahan konsep pada soal nomor 4. Dari soal dapat kita ketahui bahwa pertanyaan dari soal yaitu "Berapakah jumlah pisang yang diproduksi oleh rumah produksi tersebut selama 1 tahun?" maka jika kita pahami kembali soal yang diberikan, untuk menghitung jumlah pisang yang produksi dalam satu tahun, kita dapat menggunakan konsep deret aritmetika. Sementara siswa menyelesaikan soal dengan menggunakan konsep barisan geometri. Dari sini dapat kita simpulkan bahwa siswa salah dalam menentukan konsep dalam menyelesaikan masalah tersebut. Contoh kesalahan konsep lainnya yang dilakukan siswa terdapat pada pengerjaan soal nomor 1 (Gambar 4).

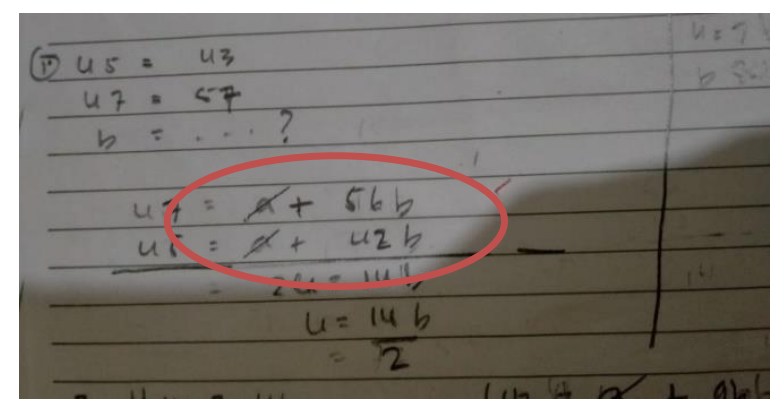

Gambar 4. Contoh Kesalahan Konsep yang Dilakukan Siswa dalam Menyelesaikan Soal Nomor 1 
Dari butir soal 1 ini untuk mendapatkan nilai beda dapat lakukan pemisalan untuk nilai suku ke5 dan ke-7 dengan menggunakan rumus $U_{n}=a+(n-1) b$, dengan n menyatakan suku ke-n Sehingga untuk suku ke-5 dapat dimisalkan dengan $U_{5}=a+4 b$ dan $U_{7}=a+6 b$. Sementara siswa menyelesaikan soal dengan memisalkan $n$ untuk suku ke- 5 dan ke-7 berturut-turut dengannilai 43 dan 57. Sehingga dari penyelesaian siswadiperoleh $U_{5}=a+42 b$ dan $U_{7}=a+56 b$.

\section{Kesalahan Prinsip}

Kesalahan prinsip yaitu kekeliruan dalam beberapa fakta atau beberapa konsep seperti kesalahan dalam menggunakan rumus. Kesalahan prinsip secara umum yang dilakukan siswa seperti tidak lengkapnya siswa menuliskan rumus, kesalahan siswa dalam menyatakan rumus barisan dan deret, serta kesalahan prinsip yang banyak terjadi adalah kesalahan yang diakibatkan tidak pahamnya siswa membedakan antar konsep barisan dan deret aritmerika dengan barisan dan deret geometri, sehingga siswa salah menggunakan rumus yang tepat. Contoh kesalahan prinsip yang dilakukan siswa pada soal nomor 8 dapat dilihat pada Gambar 5 berikut.

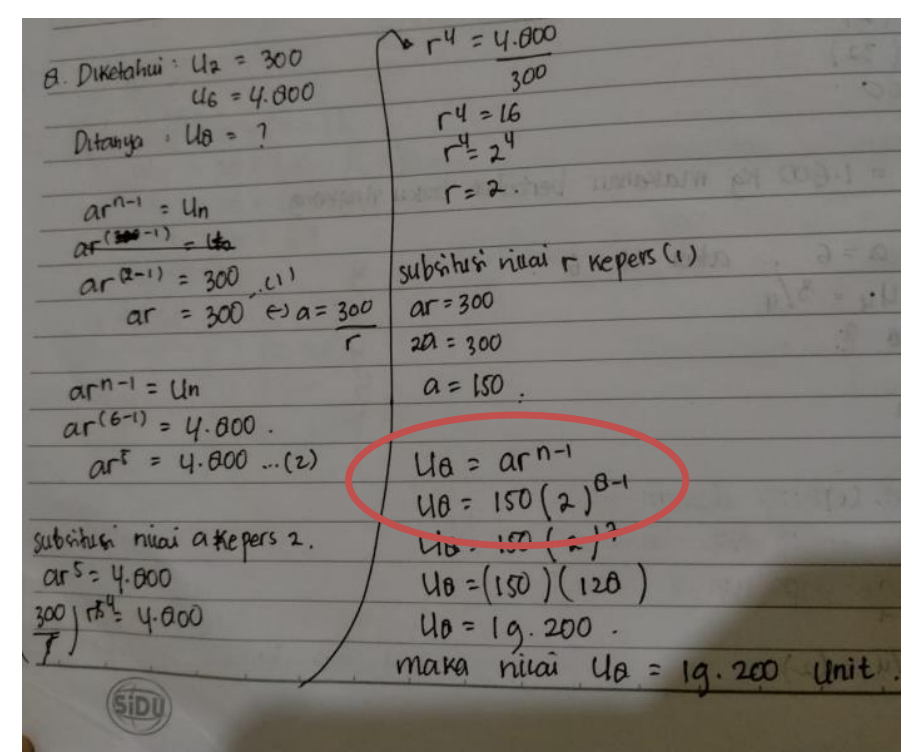

Gambar 5. Contoh Kesalahan Prinsip yang Dilakukan Siswa pada Nomor 8

Pada soal nomor 8, untuk menghitung produksi pabrik selama delapan tahun, dapat dengan menerapkan deret geometri. Sementara itu, menyelesaikan masalah tersebut dengan menerapkan konsep barisan geometri. Hal ini dapat disimpulkan bahwa siswa masih belum memahami dan belum dapat membedakan antara barisan geometri dan deret geometri. Kesalahan siswa dalam memahami konsep ini berpengaruh pada prinsip atau rumus yang digunakan siswa dalam menyelesaikan masalah, sehingga menyebabkan kesalahan prinsip. Kesalahan lainnya dapat dilihat pada Gambar 6 berikut. 


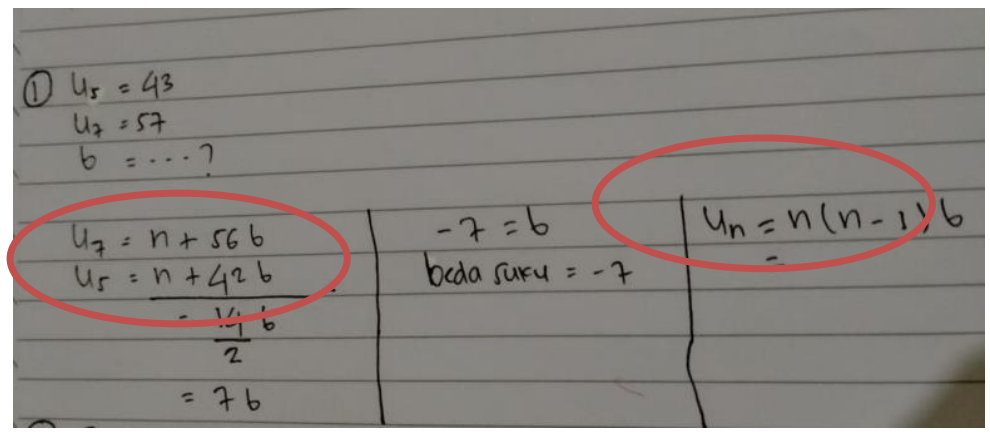

Gambar 6. Contoh Kesalahan Prinsip yang Dilakukan Siswa pada Nomor 1

Berdasarkan Gambar 6, kesalahan yang dilakukan siswa sama dengan kesalahan pada Gambar 4. Selain itu, juga terdapat kesalahan penggunaan rumus untuk menghitung nilai suku ke-n, sehingga terjadi kesalahan prinsip pada pengerjaan soal yang dilakukan siswa. Siswa menuliskan $U_{n}=n+$ $(n-1) b$, seharusnya nilai suku ke-n dinyatakan dengan rumus $U_{n}=a+(n-1) b$.

\section{Kesalahan Operasi}

Kesalahan operasi dalam penelitian ini yaitu kesalahan dalam melakukan perhitungan seperti kesalahan dalam pengoperasian penjumlahan, pengurangan, perkalian dan pembagian serta dalam pengerjaan aljabar. Contoh kesalahan operasi yang dilakukan siswa dalam mengerjakan soal barisan dan deret dapat dilihat pada gambar berikut.

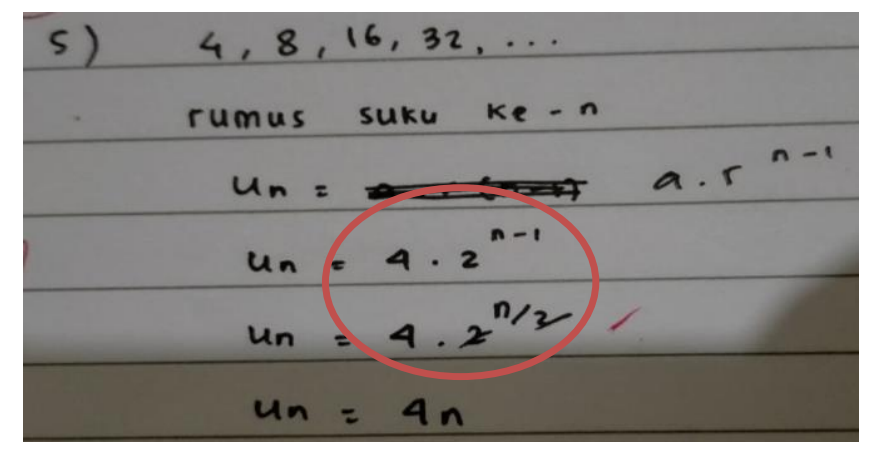

(a)

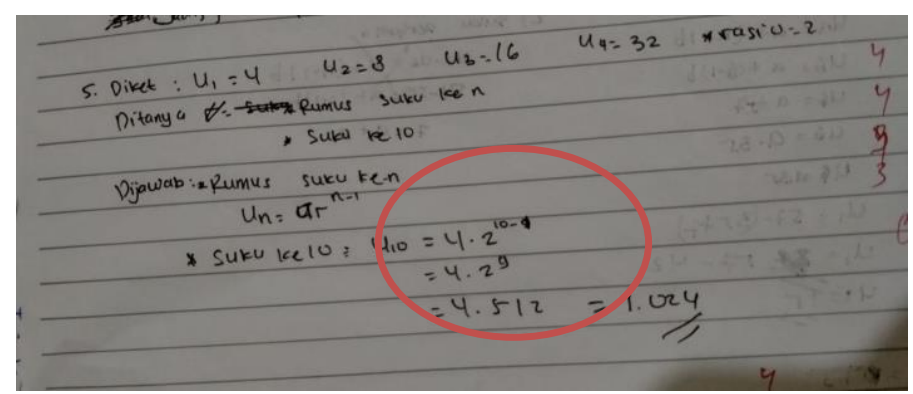

(b) 


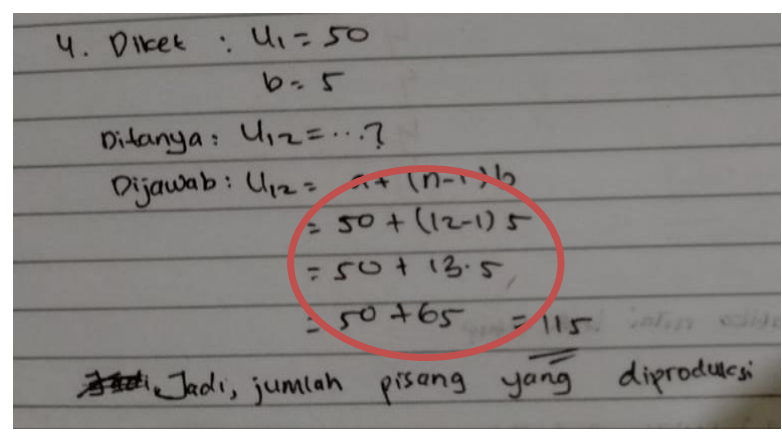

(c)

Gambar 7. Contoh Kesalahan Operasi yang Dilakukan Siswa

Pada Gambar 7 (a), terdapat kesalahan siswa dalam mengoperasikan bentuk bilangan berpangkat. Siswa menuliskan $U_{n}=4.2^{n / 2}$, seharusnya $U_{n}=2^{n+1}$. Sedangkan pada Gambar 7 (b), terdapat kesalahan siswa dalam melakukan operasi perkalian, siswa menuliskan hasil perkalian dari $4 \times 512=$ 2048. Kesalahan operasi yang dilakukan siswa pada Gambar 7 (c) adalah kesalahan dalam melakukan operasi penjumlahan. Siswa menuliskan $50+(12-1) 5=50+(13) 5$, seharusnya $50+(12-$ 1) $5=50+(11) 5$.

Berdasarkan beberapa temuan dalam penelitian terkait analisis kesalahan siswa pada materi barisan dan deret, dapat disimpulkan bahwa siswa melakukan kesalahan berupa kesalahan fakta, konsep, prinsip dan operasi. Kesalahan paling banyak dilakukan adalah kesalahan fakta dengan rata-rata persentasi $8,69 \%$ dan kesalahan yang paling sedikit dilakukan siswa adalah kesalahan operasi dengan rata-rata persentasi $2,71 \%$. Untuk mengatasi dan meminimalisir siswa melakukan kesalahan-kesalahan dalam mengerjakan soal matematika, beberapa cara diantaranya guru dapat memberikan proses pembelajaran yang mampu meningkatkan pemaham siswa terhadap konsep barisan dan deret agar siswa tidak melakukan kesalahan-kesalahan dalam mengerjakan soal barisan dan deret. Selain itu siswa sebaiknya dibiasakan untuk lebih teliti dalam membaca dan memahami permasalah yang diberikan.

\section{KESIMPULAN}

Berdasarkan hasil penelitian yang telah dilakukan di kelas XI MIPA 2 SMAN 1 Bangkinang Kota dapat disimpulkan bahwa dalam mengerjakan soal matematika, masih banyak kesalahan-kesalahan yang dilakukan oleh siswa, terutama kesalahan pada fakta, konsep, prinsip dan operasi. Adapun persentase setiap kesalahan yang dilakukan siswa adalah: (1) Rata-rata persentase kesalahan fakta yang dilakukan siswa dalam menyelesaikan soal matematika pada materi barisan dan deret adalah sebesar 8,69\%; (2) Rata-rata persentase kesalahan konsep yang dilakukan siswa dalam menyelesaikan soal matematika pada materi barisan dan deret adalah sebesar 3,79\%; (3) Rata-rata persentase kesalahan prinsip yang dilakukan siswa dalam menyelesaikan soal matematika pada materi barisan dan deret adalah sebesar 5,58\%; (4) Rata-rata persentase kesalahan Operasi yang dilakukan siswa dalam menyelesaikan soal matematika pada materi barisan dan deret adalah sebesar 2,71\%; (5) Kesalahan terbanyak yang 
Analisis Kesalahan Siswa Berdasarkan Objek Matematika pada Materi Barisan dan Deret di Kelas XI SMA/MA, Ravina Faradilla Syahril, Kartini Kartini

dilakukan siswa dalam menyelesaikan soal matematika pada materi barisan dan deret adalah kesalahan fakta dengan rata-rata persentase $8,69 \%$.

\section{UCAPAN TERIMA KASIH}

Terima kasih kepada semua pihak yang telah membantu penelitian ini, kepada orang tua, guru mata pelajaran matematika dan siswa, serta dosen yang telah memberikan bimbingannya dalam menyusun artikel ini. Penelitian ini diharapkan dapat menjadi referensi bagi semua pembaca untuk meningkatkan mutu pendidikan di Indonesia.

\section{REFERENSI}

Abdurrahman, Mulyono. (2003). Pendidikan Bagi Anak Berkesulitan Belajar. Jakarta: Tineka Cipta. Agnesti, Y., \& Amelia, R. (2020). Analisis Kesalahan Siswa Kesalahan VIII SMP Di Kabupaten Bandung Barat Dalam Menyelesaikan Soal Cerita Pada Materi Perbandingan Ditinjau Dari Gender. Jurnal Cendekia: Jurnal Pendidikan Matematika, 4(1), 151-162. https://doi.org/10.31004/cendekia.v4i1.186

Ananda, R. P., Sanapiah, S., \& Yulianti, S. (2018). Analisis Kesalahan Siswa Kelas Vii Smpn 7 Mataram Dalam Menyelesaikan Soal Garis Dan Sudut Tahun Pelajaran 2018/2019. Media Pendidikan Matematika, 6(2), 79. https://doi.org/10.33394/mpm.v6i2.1838

Aris Arya Wijaya, M. (2013). Analsis Kesalahan Siswa Dalam Menyelesaikan Soal Cerita Pada Materi Sistem Linear Dua Variabel. MATHEdunesa, 2(1).

Astuty, K. Y. (2013). Analisis Kesalahan Siswa Kelas V Dalam Menyelesaikan Soal Matematika Pada Materi Pecahan Di SDN MEDOKAN SEMAMPIR I/259 SURABAYA. MATHEdunesa, 2(3), 17.

Gustianingrum, R. A. (2021). Analisis Kesalahan Siswa Berdasarkan Objek Matematika Menurut Soedjadi pada Materi Determinan dan Invers Matriks. Mosharafa: Jurnal Pendidikan Matematika, $10(2), 235-244$.

Hamidah, D., Putri, R. I. I., \& Somakim, S. (2018). Eksplorasi Pemahaman Siswa pada Materi Perbandingan Senilai Menggunakan Konteks Cerita di SMP. Jurnal Riset Pendidikan Dan Inovasi Pembelajaran Matematika (JRPIPM), 1(1), 1. https://doi.org/10.26740/jrpipm.v1n1.p1-10

Widyawati, A., Septi, D., Afifah, N., \& Resbiantoro, G. (2018). Analisis Kesalahan Siswa Dalam Memecahkan Masalah Lingkaran Berdasarkan Taksonomi Solo Pada Kelas Viii. Jurnal Pendidikan Matematika Dan Sains, 6(1), 1-9.

Zaini, Muhammad. 2010. Analisis Kesalahan Siswa dalam Menyelesaikan Soal-Soal Matematika Pokok Bahasan Trigonometri Kelas XI MA Miftahul Qulub Polagan Galis Pamekasan Tahun Ajaran 2009-2010. Skripsi. Fakultas Keguruan Dan Ilmu Pendidikan. Universitas Madura. 